\title{
Helicobacter and Salmonella Persistent Infection Strategies
}

\author{
Denise M. Monack \\ Department of Microbiology and Immunology, Stanford University School of Medicine, \\ Stanford, California 94305 \\ Correspondence:dmonack@stanford.edu
}

Some host-adapted bacterial pathogens are capable of causing persistent infections in humans. For example, Helicobacter pylori inhabits the human gastric mucosa and persistence can be lifelong. Salmonella enterica serovar Typhi causes systemic infections that involve colonization of the reticuloendothelial system and some individuals become lifelong carriers. In this review, I compare and contrast the different lifestyles of Helicobacter and Salmonella within the host and the strategies they have evolved to persist in mammalian hosts. Persistently infected carriers serve as the reservoirs for these pathogens, and the carrier state is an essential feature that is required for survival of the bacteria within a restricted host population. Therefore, investigating the chronic carrier state should provide insight into bacterial survival strategies, as well as new therapeutic approaches for treatments.

$\mathrm{O}^{\mathrm{n}}$ $\mathrm{n}$ infection with a pathogenic microorganism, the host usually responds by activating the innate and adaptive immune responses. If the host survives the initial battle, the adaptive immune response usually clears the foreign invader. However, some pathogens have evolved the capacity to survive the initial robust immune response and persist. The persistent phase of infection usually involves a complex balance of protective immunity and immunopathology. The interactions between the host and pathogen are very complex and likely reflect the coevolution and fine tuning of bacterial virulence mechanisms and host immune responses.

Persistent colonization with the human-specific bacterial pathogens Helicobacter pylori and Salmonella enterica serovar Typhi (S. Typhi) are usually not clinically apparent. However, even in the absence of clinical symptoms, infection poses some risk to the host. For example, $H$. $p y$ lori induce gastritis with varying degrees of severity. In addition, individuals who are chronically infected with $S$. Typhi have an increased risk of developing hepatobiliary cancer. Although a deeper understanding of the mechanisms of pathology and disease caused by chronic Helicobacter and Salmonella infections is important, this work focuses on the mechanisms of persistent colonization and transmission.

\section{PERSISTENT H. PYLORI INFECTIONS}

H. pylori infection is an important example of a persistent bacterial pathogen that is usually acquired in early childhood and lasts for a lifetime. The majority of those infected $(80 \%-90 \%)$ will

Editors: Pascale Cossart and Stanley Maloy

Additional Perspectives on Bacterial Pathogenesis available at www.perspectivesinmedicine.org

Copyright (C) 2013 Cold Spring Harbor Laboratory Press; all rights reserved; doi: 10.1101/cshperspect.a010348

Cite this article as Cold Spring Harb Perspect Med 2013;3:a010348 
D.M. Monack

carry and transmit $H$. pylori without any symptoms of disease (Hunt 1996; Amieva and ElOmar 2008). In some ways, H. pylori behave like commensal bacteria and not pathogens. However, this bacterium has evolved to successfully colonize the hostile environment of the human stomach in the face of a constant innate and adaptive immune response. Although most infected people do not develop disease, three main gastric phenotypes have been identified. The most common, a "benign gastritis" phenotype, is seen in asymptomatic subjects, who on the whole do not develop serious gastrointestinal disease. The second, a "duodenal ulcer" phenotype, accounts for up to $15 \%$ of infected subjects. The third, a "gastric cancer" phenotype, is more serious and affects $\sim 1 \%$ of infected subjects as a result of a chronic inflammation induced by the infection and increases the risk of gastric cancer (Hunt 1996; Amieva and El-Omar 2008). Most basic research focuses on the diseases that are caused by H. pylori, the host factors for disease, and the bacterial virulence determinants. Here, we focus on the bacterial and host factors that contribute to the ability of this pathogen to persist.

\section{Chemotaxis Is Required for Persistence}

H. pylori colonize the harsh environment of the human stomach. To survive their journey through the acidic stomach, $H$. pylori generate large quantities of cytosolic and cell surface-associated urease. Urease is an enzyme that breaks down urea to generate ammonia and carbon dioxide and transiently buffers the acidic environment (Merrell et al. 2003; Pflock et al. 2006). Rather than persisting in the lumen of the stomach, $H$. pylori have evolved mechanisms to reach and colonize a very narrow anatomical niche (25-30 $\mu \mathrm{m})$ near the surface of the epithelial cells (Schreiber et al. 2004). The ability to reach this niche is dependent on sensing $\mathrm{pH}$ gradients and chemotaxis away from low $\mathrm{pH}$ (Ottemann and Lowenthal 2002; Schreiber et al. 2004, 2005; Croxen et al. 2006). Mutant H. pylori that are defective for sensing low $\mathrm{pH}$ and chemotaxis are defective in their ability to colonize the stomachs of mice (Howitt et al. 2011; Lertsethtakarn et al. 2011). For example, CheW, CheA, CheY, and ChePep H. pylori mutants are defective for colonizing the mouse stomach when in competition with wild-type H. pylori (Terry et al. 2005; Williams et al. 2007; Howitt et al. 2011). Recent results with the ChePep-deficient $H$. pylori mutant in a mouse model suggest that chemotaxis is essential for colonizing the glands of the antrum of stomachs (Fig. 1). Both wild-type and $\Delta$ ChePep strains colonize the mucus layer overlying the stomach surface. In contrast, the $\Delta$ ChePep mutant is not found in the glandular region (Howitt et al. 2011). Taken together, these results indicate that chemotaxis is important in allowing the bacteria to colonize a specialized niche and in locating or persisting within the mid-glands. This tropism for the midglandular zone is intriguing because the gastric progenitor cells are known to reside in this region and a direct association with $H$. pylori and gastric progenitor cells could be related to the increased gastric cancer associated with $H$. pylori infection (Uemura et al. 2001; Qiao et al. 2007).

\section{Life on the Surface of Gastric Epithelial Cells}

Once the bacteria reach the microenvironment of the epithelial lining, they survive as two major populations: one that is free-swimming in the mucus gel and a second population $(\sim 20 \%)$ found directly adhered to the epithelial surface via multiple adhesins (Hessey et al. 1990; Ilver et al. 1998; Mahdavi et al. 2002). The more virulent strains of $H$. pylori have contact-dependent mechanisms to interact with and modify epithelial cells, including a type IV secretion system that injects the virulence factor CagA into host cells (Segal et al. 1999; Asahi et al. 2000; Backert et al. 2000; Odenbreit et al. 2000; Stein et al. 2000). CagA has multiple effects on epithelial cells, including the ability to modify apical junctions and perturb cell polarity (Amieva et al. 2003; Bagnoli et al. 2005; Murata-Kamiya et al. 2007; Saadat et al. 2007; Zeaiter et al. 2008). CagA affects multiple host cell signaling pathways, which are the subject of many reviews. However, the functions of CagA that benefit the bacteria have only recently been described 

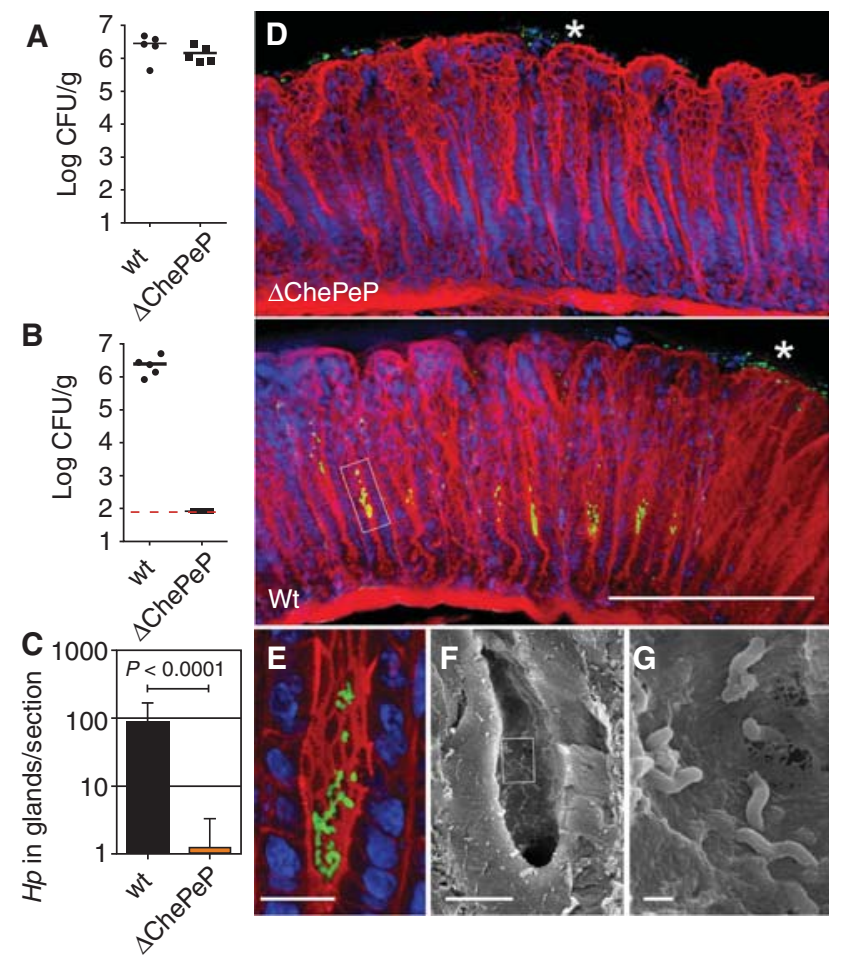

Figure 1. Chemotaxis is essential for H. pylori colonization of the antral gastric glands and colonization of the mouse stomach. (A) Colony-forming units (CFU) of H. pylori in the stomachs of mice colonized with either the wild-type or $\Delta$ ChePep mutant for 2 weeks. Each marker represents an individual mouse. (B) CFU counts from the mice coinfected with both the wild-type and $\Delta$ ChePep mutant in a 1:1 ratio for 2 weeks. The dashed line indicates the limit of detection. $P<0.0001$. $(C)$ Volumetric analysis of bacteria colonizing the antral glands calculated from $100-\mu \mathrm{m}$-thick sections imaged by three-dimensional (3D) confocal microscopy from single infections of either the wild-type or $\Delta$ ChePep mutant. (D) 3D confocal microscopy of murine stomachs infected with either wild-type or $\Delta$ ChePep mutant. F-actin is stained with phalloidin (red) and nuclei (blue), and $H$. pylori cells (green) are immunolabeled. Asterisks indicate $H$. pylori cells in the surface mucus of the stomach, whereas a box highlights bacterial colonies in mid-glands. $(E)$ Magnified view of the area boxed in panel $D .(F)$ Scanning electron microscopy (SEM) of wild-type infected gland. $(G)$ Magnified view of area boxed in panel $F$. Scale bars, $100 \mu \mathrm{m}(D), 10 \mu \mathrm{m}(E)$ and $(F)$, and $2 \mu \mathrm{m}(G)$. Hp, Helicobacter pylori; wt, wild type.

(Hatakeyama 2004; Peek 2005; Suzuki et al. 2006; Handa et al. 2007; Hatakeyama 2008; Backert et al. 2010, 2011; Murata-Kamiya 2011). Using a polarized epithelium model system, CagA was found to play an important role in enabling $H$. pylori colonization of the epithelium (Tan et al. 2009). This occurs via a local perturbation of epithelial integrity and enables $H$. pylori to grow as microcolonies adhering to the host cell surface even in conditions that do not support growth of free-swimming bacteria (Fig. 2) (Tan et al. 2009). H. pylori alter the internalization, intracellular transport, and po- larity of the transferrin/transferrin receptor iron uptake system by a mechanism that depends on CagA and another major virulence factor, VacA (Tan et al. 2011). CagA is important in promoting iron acquisition in vivo. This was shown in a Mongolian gerbil model by comparing wild-type and CagA-deficient strains for their ability to colonize gerbils. Although wildtype and CagA-deficient strains of $H$. pylori colonize iron-replete gerbils to the same extent, the cagA deletion mutants are markedly impaired in colonizing iron-deficient gerbils (Tan et al. 2011). These findings suggest that $H$. pylori 
D.M. Monack
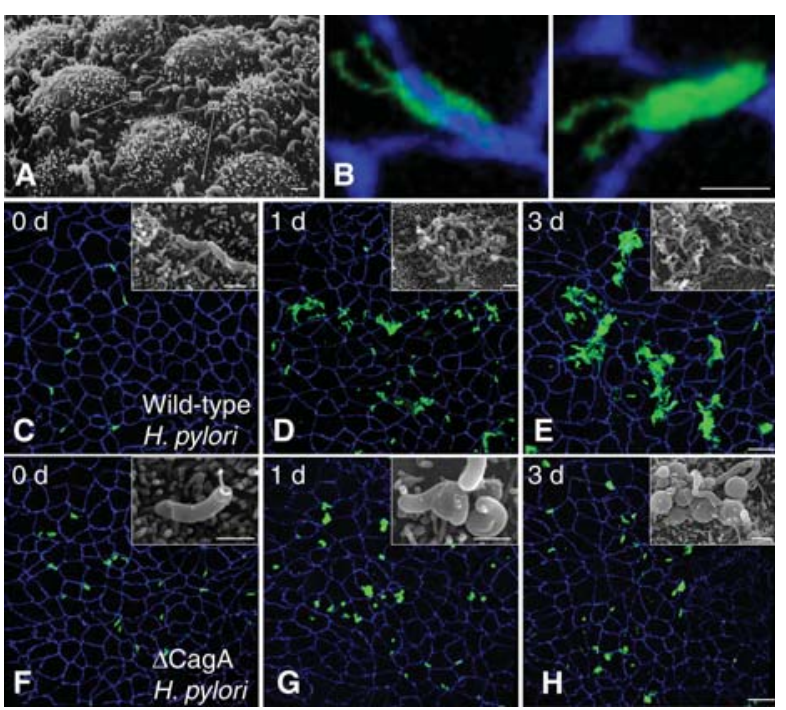

Figure 2. Formation of $H$. pylori microcolonies on the surface of epithelial cells requires CagA. (A) SEM of the gastric epithelial cell surface from a prepyloric biopsy from a patient with duodenal ulceration. The domeshaped surfaces are gastric epithelial cells. Bacteria are located in the junctions or gutters between host cells (Steer 1984). (B-D) 3D confocal images of $H$. pylori colonizing the cell surface of polarized MDCK cells in the Transwell system described by Tan et al. (2009). View from below the junctions (left) and above the junctions (right). Bacteria are visualized with anti-H. pylori antibodies (green) and cell junctions are stained blue (antiZO-1). (C) Wild-type H. pylori is tightly adhering to junctions between epithelial cells. Scale bar, $1 \mu \mathrm{m}$. $(C-E)$ Low-magnification 3D confocal images of wild-type $H$. pylori forming microcolonies on epithelial cells. Scale bar, $10 \mu \mathrm{m}$. Insets show replicating wild type as visualized by SEM. Scale bar, $1 \mu \mathrm{m}$. $(F-H)$ Low-magnification 3D confocal images of $\Delta$ cagA H. pylori colonizing the surface of epithelial cells. Scale bar, $10 \mu \mathrm{m}$. Insets show CagA mutant colony morphology as visualized by SEM. Scale bar, $1 \mu \mathrm{m}$.

have evolved multiple mechanisms to manipulate the epithelium to acquire micronutrients (e.g., iron) from host cells and to grow on the cell surface.

\section{Immune Evasion Strategies}

The immunomodulatory effects of VacA and CagA and some of the $H$. pylori adhesins have been reviewed elsewhere (Monack et al. 2004b; Backert and Clyne 2011; Backert et al. 2011; Murata-Kamiya 2011; Tegtmeyer et al. 2011). In addition, a number of $H$. pylori factors have evolved to reduce recognition by the innate immune system. For example, $H$. pylori make flagellin molecules that are not recognized by TLR 5 (Gewirtz et al. 2004). The mutations in H. pylori flagellin lead to evasion map to the TLR5 recognition domain, amino acids 89-96 of the amino-terminal D1 domain of flagellin (Andersen-
Nissen et al. 2005). Mutations in these residues destroy motility in Salmonella. However, H. pylori and other $\alpha$ and $\varepsilon$ Proteobacteria possess compensatory amino acid changes in other regions of the flagellin molecule that then allow them to evade TLR5 recognition and retain motility, a phenotype that is crucial for virulence (Andersen-Nissen et al. 2005).

In addition, $H$. pylori evade signaling through TLR4, which recognizes lipopolysaccharide (LPS). H. pylori make an LPS that is 1000 times less pyrogenic and 500-fold less toxic than other Gram-negative enteric bacteria, such as Salmonella (Moran 2007). This evasion is thought to be due to underphosphorylation, underacylation, and substitution of long-chain fatty acids in the lipid A moiety of $H$. pylori (Moran 2007). In addition, modifications in the $H$. pylori LPS may act as molecular mimics of human glycans to avoid immune recognition. 
H. pylori possess several enzymes that may modify LPS with carbohydrate groups resembling human Lewis blood group antigens (Moran 2008).

\section{Transmission}

Although there is a very large population of humans throughout the world that is colonized with $H$. pylori, relatively little is known about how it is transmitted. Epidemiologic studies of H. pylori transmission show that the majority of infections tend to occur within families through close person-to-person contact (Falush et al. 2003; Linz et al. 2007). Most transmission occurs in childhood, and maternal-to-child and sibling-sibling transmission seem most likely (McCallion et al. 1996; Bardhan 1997; Kivi et al. 2005; Weyermann et al. 2006). Although viable $H$. pylori have not been isolated from many sources, such as sewage and water sources, H. pylori DNA is present, suggesting that they are a source of infective H. pylori (Brown 2000). However, it seems more likely that transmission occurs in situations in which gastric content can be transferred quickly from person to person. For example, gastric-oral transmission is suggested in association with gastroenteritis with vomiting (Brown 2000). Fecal-oral transmission may also be possible. Thus far, the contribution of specific $H$. pylori factors in transmission have not been studied or identified.

\section{PERSISTENT SALMONELLA INFECTIONS}

Salmonella enterica is a pathogenic bacterial species that is an important cause of disease in humans ranging from gastroenteritis to systemic infections (Monack et al. 2004b). Host-adapted Salmonella serovars disseminate from the gastrointestinal tract and colonize systemic sites. For example, S. enterica serovar Typhi (S. Typhi) causes human typhoid fever, whereas S. enterica serovar Typhimurium ( $S$. Typhimurium) has a broad host range, causing disease in a variety of animals. Strains of $S$. Typhimurium cause a typhoid-like disease in mice and usually cause a self-limiting gastroenteritis in healthy human adults. However, $S$. Typhimurium can cause sys- temic infections in humans (Kariuki et al. 2006; Gordon et al. 2008; Dhanoa and Fatt 2009; Sigauque et al. 2009; Yen et al. 2009). Indeed, recent cases of invasive and recurrent infections in Malawi, Mozambique, Malaysia, and Taiwan were caused by nontyphoidal Salmonella (NTS), which were largely comprised of multidrug-resistant $S$. Typhimurium strains (Kariuki et al. 2006; Gordon et al. 2008; Dhanoa and Fatt 2009; Sigauque et al. 2009; Yen et al. 2009).

S. Typhi and S. enterica serovar Paratyphi (S. Paratyphi) are important human pathogens of immense concern to the public health (Parry et al. 2002). They are endemic in regions of the world where drinking water quality and sewagetreatment facilities are poor (Parry et al. 2002; Monack et al. 2004b). Chronically infected humans are the reservoirs for the spread of infection and disease.

Salmonella enters the host through the gastrointestinal tract and translocates by multiple mechanisms to deeper tissues (Kohbata et al. 1986; Jones et al. 1994; Vazquez-Torres et al. 1999). In order for the infection to extend beyond the intestinal mucosa, Salmonella must survive and replicate in macrophages, a privileged niche that allows Salmonella to elude the adaptive immune response (Jones and Falkow 1996; Cirillo et al. 1998; Deiwick et al. 1998; Hensel et al. 1998; Cheminay et al. 2005; Tobar et al. 2006; Halici et al. 2008; Haraga et al. 2008). A significant percentage $(1 \%-6 \%)$ of typhoid patients become chronic carriers of $S$. Typhi, as do many people who have never had a clinical history of typhoid fever (Levine et al. 1982; Monack et al. 2004b). These individuals serve as a reservoir of infections as the bacteria are periodically shed and transmitted to new hosts (Vogelsang and Boe 1948).

What is the immune state of human typhoid carriers? Optimal operation of IL-22- and IFN$\gamma$-dependent immunity and T-cell function appear to be essential for the eradication of Salmonella from reservoirs within the reticuloendothelial system (Mastroeni and Menager 2003; Dougan et al. 2011). However, the human carrier state could be associated with an incapacity to develop an effective immune response 
D.M. Monack

(Thompson et al. 2009), although further studies of typhoid patients are needed to confirm this observation. Chronic carriers likely have genetic or other more transient or stochastic differences (e.g., disruption of indigenous intestinal microbiota) that predispose them to an immune state that allows for the establishment of this "equilibrated" state. This response can be efficient enough to survive the acute peak of infection, but too weak to allow eradication of the bacteria from the host.

Mechanisms of $S$. Typhi Evasion of Innate Immunity and Persistence in the Gallbladder

There are several strategies that $S$. Typhi use to evade detection by the host innate immune system (Tsolis et al. 2008). Genome sequencing revealed a unique region in the $S$. Typhi genomedesignated Salmonella pathogenicity island 7 (SPI-7) (Baker and Dougan 2007). SPI-7 encodes functions for the production and export of the Vi-capsular polysaccharide antigen. The Vi capsule is expressed during infections of humans with $S$. Typhi and appears to be important for pathogenesis in humans and cultured human colonic epithelial cells ( Tran et al. 2010). The Viantigen plays a role in evading detection of $S$. Typhi by Toll-like receptor 4, perhaps by "masking" detection of lipopolysaccharide (Wilson et al. 2008). In addition, they have shown that TviA, a SPI-7-encoded regulatory protein that controls Vi expression, flagellar motility, and the invasion-associated type 3 secretion system (T3SS) on SPI-1, is essential for the appropriate timing of virulence factor expression in the gastrointestinal tract (Wilson et al. 2008; Winter et al. 2009). Indeed, their findings suggest that TviA-mediated repression of flagellin expression helps $S$. Typhi avoid detection by host TLR5 (Winter et al. 2008).

Chronic infections with $S$. Typhi are classically associated with long-term excretion of bacteria and localization in the gallbladder (Young et al. 2002). Although humans who carry Salmonella chronically often have biliary tract disease, this condition is not an absolute requirement for development of the carrier state (Dinbar et al. 1969; Levine et al. 1982; Monack et al. 2004b). There is a strong correlation with the presence of gallstones and conversion to the chronic carrier state in a study conducted in typhoid-endemic Mexico City (Crawford et al. 2010; Gonzalez-Escobedo et al. 2011). The bile, a lipid-rich, detergent-like digestive secretion with antimicrobial properties present in the gallbladder induces the production of an exopolysaccharide matrix $\mathrm{O}$-antigen that facilitates $S$. Typhi biofilm formation on human gallstones (Crawford et al. 2008; Hall-Stoodley and Stoodley 2009). Gallstone biofilms may promote carriage of this bacterial pathogen in the gallbladder and may lead to reseeding of the intestine, fecal shedding, and transmission to a new host. Indeed, mice fed a lithogenic diet developed cholesterol gallstones that supported biofilm formation during persistent $S$. Typhimurium infection and, as a result, showed enhanced fecal shedding and enhanced colonization of the gallbladder and bile (Crawford et al. 2010).

\section{S. TYPHIMURIUM PERSISTENCE IN MICE}

To study the basic aspects of host-pathogen interactions during the carrier state, models of long-term chronic S. Typhimurium infection in mice have been established. The genetic background of the mouse strain plays a pivotal role in determining Salmonella persistence (Hormaeche 1979). Nramp1 is a genetic locus originally identified as being a critical factor in host defense against intracellular pathogens including Leishmania, Mycobacteria, and Salmonella (Vidal et al. 1993). The Nramp1 gene codes for an ion transporter and is expressed primarily in macrophages and dendritic cells (DC) (Vidal et al. 1993; Govoni et al. 1995). Commonly used mouse strains such as C57BL/ 6 carry two-point mutations resulting in increased susceptibility to intracellular pathogens. As a result, chronic infection models in $\mathrm{C} 57 \mathrm{BL} / 6$ mice require attenuated Salmonella strains. Virulent S. Typhimurium strains cause a persistent infection in Nramp $1^{w t / w t}$ mice or their F1 hybrids (Monack et al. 2004a; Johanns et al. 2010). Oral inoculation of up to $10^{8} \mathrm{CFU}$ results in a persistent infection in which bacteria can be found within macrophages in the mesenteric lymph nodes up 
to 1 year postinoculation (Fig. 3) (Monack et al. 2004a).

S. Typhimurium persist within macrophages in the reticuloendothelial system. The metabolic state of these persisting bacteria is not known. However, results of a recent study conducted in bone marrow-derived macrophages and splenocytes from susceptible mice indicate that many intracellular bacteria do not replicate, but appear to enter a dormant-like state (Helaine et al. 2010). In addition, S. Typhimurium survival and replication in hemophagocytic macrophages may help establish persistent infection (Nix et al. 2007).

The Salmonella factors that contribute to virulence have been extensively studied and reviewed elsewhere (Haraga et al. 2008; Ibarra and Steele-Mortimer 2009; McGhie et al. 2009; Valdez et al. 2009). However, it is unclear which of these or other bacterial factors are required specifically for persistent Salmonella infection. Much effort has been concentrated on the secreted effector proteins that depend on the type III secretion systems encoded by Salmonella pathogenicity islands 1 and 2 (SPI1 and SPI2, respectively). Yet, the extent to which these pathogenicity islands actually contribute to persistent infection remains uncertain. Clearly, a variety of Salmonella factors that are independent of SPI1 and SPI2 also play significant roles in persistent infection. Therefore, I will discuss both SPI1- and SPI2-dependent and -independent factors that have been reported to play a role during the persistent phase of Salmonella infection. Because much of the work investigating persistent Salmonella infection has used $S$. Typhimurium, this section of the review will concentrate on the bacterial factors from this serovar.

\section{SPI1 and SPI2}

The pathogenicity islands SPI1 and SPI2 encode two distinct type III secretion systems. Each translocates a specific group of bacterial effector proteins into host cells. SPI1-dependent translocation of bacterial invasion factors into host epithelial cells enables $S$. Typhimurium to penetrate the small intestines and Peyer's patches (Galan 2001), accomplishing an initial step of $S$. Typhimurium-dissemination from the gastrointestinal tract to host systemic sites (including the MLN, spleen, liver, and bone marrow). To search for Salmonella factors that contribute to later stages of infection ( persistent infection), a negative-selection screen was undertaken using a transposon-mutagenized library of $S$. Typhimurium and the Nramp1 ${ }^{r}$ wild-type mouse strain 129X1/SvJ (Lawley et al. 2006). Although the mice were inoculated intraperitoneally instead of orogastrically (a route that bypasses the significant bottleneck that occurs during dis-

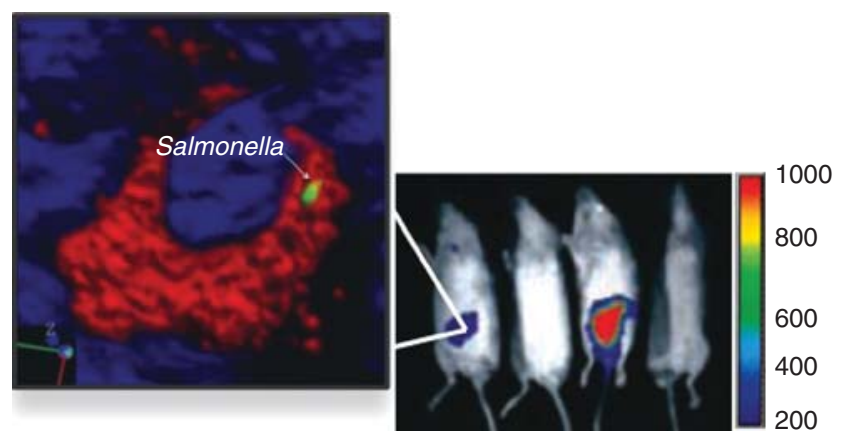

Figure 3. S. Typhimurium persist in macrophages within the mesenteric lymph nodes (MLN) of 129Sv mice. $129 \mathrm{~Sv}$ mice were inoculated by oral administration of the bioluminescent labeled wild-type $S$. Typhimurium strain, SL1344hha::Tn5lux at a dose of $10^{8} \mathrm{CFU}$ and monitored for more than 80 days (Monack et al. 2004a). Light intensity is represented by a color scale in counts. S. Typhimurium (labeled with anti-S. Typhimurium antibodies in green) persist in the MLN and are found in macrophages (labeled with antimacrophage antibody, MOMA-2 in red). Nuclei are stained with a DNA dye, ToTo3, in blue. 
D.M. Monack

semination from the gastrointestinal tract to systemic sites [Meynell 1957; Meynell and Stocker 1957; Mecsas et al. 2001]), the screen revealed that SPI1 was necessary to sustain a persistent infection for at least 1 month postinfection (Lawley et al. 2006). The SPI1 genes confirmed to be required for persistent infection in this study included the invasion and translocation effectors SipB, SipC, and SipD; however, it is possible that additional SPI1 effectors also could contribute to persistent infection. In light of the fact that $S$. Typhimurium is extruded from dying cells in the epithelia throughout an infection (Knodler et al. 2010), it is likely that the ability of $S$. Typhimurium to continuously reinvade epithelial tissues is necessary to sustain a persistent infection. In support of this notion, SPI1 is also required for a persistently infected mouse to transmit $S$. Typhimurium to naïve cage-mates (Lawley et al. 2008).

\section{S. Typhimurium Modulates Host Cell Migration: A Trait that Mediates Persistent Infection}

In addition to identifying SPI-1, this same negative-selection screen in mice identified many SPI-2 genes (Lawley et al. 2006). Although most SPI-2 genes were required for initial colonization of the spleen, the SPI-2 effector SseI did not emerge from the screen until 2 weeks postinfection, indicating that SseI plays a role in long-term carriage. SseI is a secreted effector that is expressed by intracellular Salmonella and translocated across the vacuolar membrane into the host cell cytosol via the SPI-2-encoded T3SS (Miao and Miller 2000). In a subsequent study, it was shown that $\mathrm{SseI}$ is required for maintaining a long-term systemic infection in mice by modulating normal cell migration of primary macrophages and DC (McLaughlin et al. 2009). The ability to inhibit migration requires the host factor IQ-motif-containing GTPase-activating protein 1(IQGAP1), an important regulator of host cell migration. SseI binds directly to IQGAP1 and colocalizes with this factor at the cell periphery. Furthermore, $S$. Typhimurium inhibits DC, which are potent antigen-presenting cells that are vital to activating T-cell migration toward CCL19. Although the exact mechanism by which SseI modulates migration is still not clear, it seems to play a role in subverting the onset of adaptive immunity as spleens from mice infected with the sseI mutant contained more DC and $\mathrm{CD}^{+}{ }^{+} \mathrm{T}$-lymphocytes compared to mice infected with wild-type $S$. Typhimurium (McLaughlin et al. 2009). It should be noted that $S$. Typhi and NTS isolates do not contain sseI. In addition, there are sseI-independent mechanisms by which S. Typhimurium modulates DC migration in vivo (McLaughlin et al. 2009). Future studies are needed to identify additional novel "migration modulation" factors in Salmonella.

In addition, it is important to note that sseI is a pseudogene in $S$. Typhi. The molecular bases for $S$. Typhi's host restriction and unique pathogenic attributes are just beginning to be understood, but they are believed to be the result of a combination of genome degradation and the acquisition of new genetic information (Retamal et al. 2010; Sabbagh et al. 2010; Trombert et al. 2011; Spano and Galan 2012; Song et al. 2013). For example, the proteolytic targeting of a host GTPase, Rab29, by an effector protein, GtgE, that is present in S. Typhimurium and not $S$. Typhi distinguishes the intracellular compartments of human-adapted Typhi and the broad-host S. Typhimurium (Spano and Galan 2012). Several functional studies indicate that $S$. Typhi pseudogenes contribute to its adaptation to humans (Retamal et al. 2010; Trombert et al. 2011). Perhaps the role of sseI is similar.

\section{The Role of Foxp $3^{+}$Regulatory T cells in Salmonella Persistence}

The pathological damage that results from continued macrophage activation will, at some stage of the infection, outweigh the immediate risk that is posed by the residual, persisting Salmonella, and the immune response likely turns itself off, allowing bacterial persistence. Regulatory T cells (Tregs) have been implicated in playing a critical role in sustaining this balance in many infections. The role of Tregs during Salmonella persistence was recently investigated in a mouse model of persistence (Johanns et al. 2010). The 
role of Tregs during chronic infection with Leishmania major, viruses, Mycobacterium tuberculosis, Schistosoma mansoni, and Plasmodium berghei has been characterized (Long et al. 2003; Suvas et al. 2003; Hesse et al. 2004; Hisaeda et al. 2004; Suvas et al. 2004). Interestingly, these studies suggest that Treg-mediated immune suppression can provide both detrimental and protective roles in host defense against these pathogens (Uzonna et al. 2001; Suvas et al. 2003; Hesse et al. 2004; Mendez et al. 2004). Johanns et al. show that early after infection with $S$. Typhimurium, when the bacterial burden is progressively increasing, the activation of protective immune components is delayed, and this coincides with increased Treg cell suppressive potency (Johanns et al. 2010). In contrast, later during infection, when reductions in bacterial burden occur, protective immune components are highly activated and Treg cell suppressive potency is reduced (Johanns et al. 2010). They also found that when Tregs were ablated early after infection, when their suppressive potency is increased, there was an accelerated bacterial eradication. This study suggests that Tregs control the early stages of setting up a persistent Salmonella infection.

\section{Salmonella Factors Required for Intestinal Persistence}

Sustained colonization of the gastrointestinal tract is another important aspect of persistent Salmonella infection because it is necessary for live bacteria to be passed in the feces and eventually transmitted to other potential hosts (Lawley et al. 2008). Using the CBA mouse strain (Nramp ${ }^{r}$, S. Typhimurium-resistant), several Salmonella adherence factors were shown to be important for intestinal persistence of S. Typhimurium. The fibronectin-binding factors, ShdA and MisL, contribute significantly to persistence in the gastrointestinal tract and fecal shedding of live bacteria (Kingsley et al. 2000, 2002a,b, 2004; Dorsey et al. 2005). In addition, several fimbrial operons (encoding outer surface structures with possible adhesive functions), including $l p f, b c f$, $s t b, s t c, s t d$, and $s t h$, are also required for longterm intestinal carriage and fecal shedding
(Weening et al. 2005). In the Salmonella persistence screen described above, several genes from these operons were negatively selected, including $s t c C$, stcD, sth $A, b c f D$, stbD, and $s t d A$, indicating a link between intestinal persistence and systemic persistence (Lawley et al. 2006). For example, the antivirulence modulator ZirTS is expressed only by $S$. Typhimurium colonizing the gastrointestinal tract (as well as in the feces of persistently infected mice), and such expression negatively impacts systemic colonization in Nramp1 $1^{r}$ mice (Gal-Mor et al. 2008). How ZirTS expression affects systemic persistence requires further investigation.

$S$. Typhimurium factors that protect against host-derived antimicrobial peptides also contribute to persistent Salmonella infection. For example, it was recently shown that several Salmonella factors are required for $S$. Typhimurium carriage in the intestines of Caenorhabditis elegans, including SPI-2, pSLT (virulence plasmid), PhoPQ (a sensor/kinase system that senses antimicrobial peptides (Bader et al. 2005), acidic $\mathrm{pH}$ (Bearson et al. 1998), and changes in metal cation concentration (Groisman et al. 1997; Alegado and Tan 2008). The PhoPQ regulon encompasses genes that protect against antimicrobial peptides such as polymixin B, C18G, and CRAMP, such as pgtE and mig-14 (Guina et al. 2000; Brodsky et al. 2005; Alegado and Tan 2008). PgtE, a modifier of the bacterial outer surface membrane, was also identified in one of the Salmonella persistence screens performed by Lawley et al. (2006) Mig-14, along with several other Salmonella factors providing resistance toward antimicrobial peptides (VirK, RcsC, and YdeI) also contribute to persistent Salmonella infection (Detweiler et al. 2003; Erickson and Detweiler 2006). These results show that Salmonella resistance toward antimicrobial peptides of the host immune response is critical for Salmonella to maintain persistent infection in systemic sites.

\section{Transmission}

Host-to-host transmission of a pathogen ensures its successful propagation and maintenance within a host population. Although this 
D.M. Monack

is an essential stage of a pathogen's life cycle, very little is known at a molecular level about this aspect of infection (Lipsitch and Moxon 1997; Ebert and Bull 2003). Transmission is a complex process involving components of both the pathogen and the host (Fig. 4). For example, Salmonella must contend with the indigenous microbiota, the host innate immune system, and the establishment of a replicative niche. Salmonella must also facilitate exit and spread to other hosts and finally, successfully colonize and multiply within a new host, thus repeating the cycle.

Understanding the host factors that affect $S$. Typhimurium colonization of the gut is very important for controlling persistence and transmission. Some host factors have been identified (Mastroeni and Grant 2011). For example, B cells and innate secretory antibodies contribute to control the spread of Salmonella beyond the gut (Mittrucker et al. 2000). IgM-/- mice have lower $\mathrm{LD}_{50}$ after oral infection and $\mathrm{Pigr}^{-/-}$, which are unable to bind and actively transport dimeric IgA and pentameric IgM to mucosae, are more susceptible (Wijburg et al. 2006). In addition, the indigenous microbiota plays an important role in protecting the gut from colonization by pathogens by multiple mechanisms (Stecher and Hardt 2011). On the other hand, Salmonella has evolved multiple ways to survive in the gut. For example, $S$. Typhimurium requires intestinal inflammation to grow in the gut by using its virulence factors to invade the intestinal epithelium and survive in mucosal macrophages (Stecher et al. 2007; Barman et al. 2008; Lawley et al. 2008). In addition, Winter et al. has shown recently that reactive oxygen species generated during inflammation react with endogenous, luminal sulphur compounds (thiosulphate) to form a new respiratory electron acceptor, tetrathionate (Winter et al. 2010). The genes encoded by the trSR ttrBCA gene cluster confer the ability to use tetrathionate as an electron acceptor, thus providing a growth advantage for $S$. Typhimurium over the competing microbiota in the lumen of the inflamed gut (Bäumler and Fang 2013). In addition, fimbrial and autotransporter adhesins mediate persistence in the gut (Kingsley et al. 2000, 2002a,b, 2004; Humphries et al. 2001; Wagner and Hensel 2011) and possibly other tissues (Lawley et al. 2006).

Once Salmonella has colonized the gut, what are the factors that govern transmission? Using a natural model of persistently infected mice, it was found that a subset of the infected mice ( $\sim 30 \%)$, termed supershedders, shed high levels $\left(>10^{8} \mathrm{CFU} / \mathrm{g}\right)$ of $S$. Typhimurium in their feces and, as a result, rapidly transmit infection (Lawley et al. 2008). Although most of the infected mice show signs of intestinal inflammation, only supershedder mice develop colitis. It was shown that development of the supershedder phenotype depends on the virulence determinants SPI- 1 and -2 , and it is characterized by mucosal invasion and, importantly, high luminal abundance of $S$. Typhimurium in the colon. In addition, the treatment of mice with antibiotics that alter the indigenous intestinal microbiota rapidly induces the supershedder phenotype and leads to rapid transmission to naïve hosts. Importantly, a single dose of an antibiotic given to chronically infected mice (125 days postinfection) reactivated the supershedder phenotype in mice that were not shedding detectable levels of $S$. Typhimurium, demonstrating that the intestinal microbiota has a role in controlling persistent disease (Lawley et al. 2008). Although, this model has established laboratory conditions that ensure that animals exposed to $S$. Typhimurium become supershedders, it is still not understood what circumstances dictate whether animals with identical genes and exposed to the identical inoculum become persistently infected and shed at low or moderate levels or become supershedders with significant pathology. Future studies are required to determine whether specific conditions lead to supershedders or whether it is a stochastic event. What determines the creation of a murine version of "Typhoid Mary?"

As mentioned previously, a theory to explain typhoid carriage proposes that bacteria originating from the systemic sites seed the intestinal tract through the gallbladder. Perhaps the bacteria that seed the intestinal tract from the gallbladder are "primed" to express crucial metabolic pathways and transmission factors that help the pathogen outcompete the indigenous 
Helicobacter/Salmonella: Infection Strategies

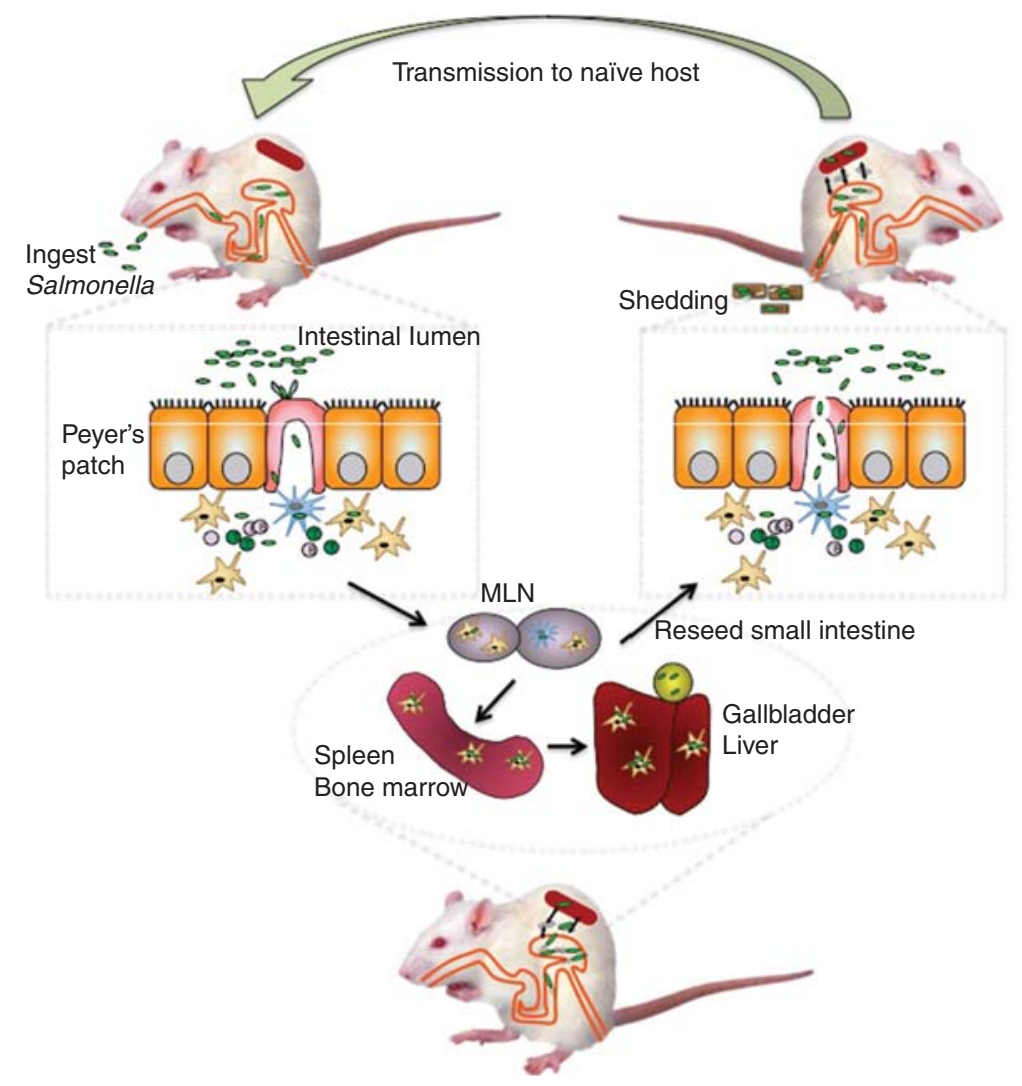

Figure 4. Life cycle of Salmonella in mammalian hosts. Bacteria are ingested in contaminated food or water and enter the gastrointestinal tract. Salmonella enters the Peyer's patches of the intestinal tract mucosal surface by invading $\mathrm{M}$ cells-specialized epithelial cells that take up and transcytose luminal antigens for uptake by phagocytic immune cells. This is followed by inflammation and phagocytosis of bacteria by neutrophils, macrophages, and DC. In systemic salmonellosis, such as typhoid fever, Salmonella may target specific types of host cells, such as DC and macrophages that favor dissemination through the lymphatics and bloodstream to the MLNs and deeper tissues. This then leads to transport to the spleen, bone marrow, liver, and gallbladder. Bacteria can persist in the MLNs, bone marrow, and gallbladder for life, and periodic reseeding of the mucosal surface via the bile ducts and/or the lymphatics occur, and shedding can take place from the mucosal surface. Some mice that are infected orally with $S$. Typhimurium develop a supershedder phenotype $(\sim 30 \%)$. Supershedders shed high levels $\left(>10^{8} \mathrm{CFU} / \mathrm{g}\right)$ of $S$. Typhimurium in their feces, and as a result, rapidly transmit infection. Some of the factors that influence the supershedder phenotype include: Salmonella virulence factors, gut inflammation, indigenous intestinal microbiota, and antibiotic treatment. Factors that influence efficient transmission could include survival in the environment (Foster 1995; Lee et al. 1995; Lin et al. 1995; Spector 1998; Scher et al. 2005; White et al. 2006, 2008). For example, the Salmonella rdar (red, dry, and rough) morphotype, a multicellular phenotype characterized by fimbria- and cellulose-mediated colony pattern formation, has been linked to survival in nutrient-limited environments and may enhance Salmonella survival outside the host, thereby aiding in transmission between hosts (White et al. 2006, 2008). In addition, there could be additional transmission-specific factors or conditions that aid in efficient transmission, similar to what has been described for Vibrio cholera (Merrell et al. 2002). Finally, factors within the naïve host that influence efficient transmission include survival in the acidic conditions of the stomach (Foster 1995), alterations in the indigenous intestinal microbiota that could be induced by alterations in diet (Sonnenburg et al. 2010), immune state (Dhanoa and Fatt 2009), or recent antibiotic treatment (Riley et al. 1984). 
D.M. Monack

intestinal microbiota even in the absence of antibiotic treatment. Certainly, the finding that antibiotic treatment induces the supershedder phenotype has relevance to understanding how antibiotic therapy is a risk factor for the development of salmonellosis (Riley et al. 1984), gastroenteritis associated with antibiotic-resistant S. Typhimurium (Glynn et al. 2004), and increased transmission of antibiotic-resistant S. enterica in poultry (Bauer-Garland et al. 2006). These findings indicate that alterations in the intestinal microbiota caused by antibiotic use may induce fecal shedding and transmission of enteric pathogens.

\section{MECHANISMS OF INTESTINAL MICROBIOTA CONTROLLING SALMONELLA COLONIZATION}

The indigenous intestinal microbiota plays an important role in maintaining health (Sekirov et al. 2010). It provides digestive functions, modulates host metabolism, and stimulates development of lymphatic tissue and the mucosal immune system (Rakoff-Nahoum et al. 2004; Mazmanian et al. 2005; Cash et al. 2006). Importantly, it can efficiently limit infection of the gut by pathogenic microbes (Sonnenburg et al. 2010; Salzman 2011). Some of the microbiotamediated mechanisms of protection include (1) blocking growth of invading pathogen by a mechanism referred to as colonization resistance, (2) priming the host's innate and adaptive immune defenses, and (3) helping eliminate the pathogen from the gut lumen at the end of infection. The role of colonization resistance during Salmonella infection has recently been reviewed and could include direct inhibition, nutrient depletion, and stimulation of immune defenses (Stecher and Hardt 2011). In addition to colonization resistance, it has been shown in a model of Salmonella diarrhea that the microbiota mediates $S$. Typhimurium clearance from the gut lumen (Endt et al. 2010). It was very nicely shown that the Salmonella-elicited secretory IgA (sIgA) prevents disease when the animal is infected with $S$. Typhimurium for a second time. However, sIgA was dispensable for pathogen clearance from the gut. Instead, clear- ance was mediated by the microbiota, which was necessary and sufficient for terminating longterm fecal shedding. These results have implications for developing diet- or microbiota-based therapies for curing Salmonella infections in humans (Sonnenburg et al. 2006, 2010; Bolam and Sonnenburg 2011).

\section{CONCLUDING REMARKS}

Bacterial persistence and host-to-host transmission are key phases of a pathogen's life cycle and represent a window when there can be intervention to reduce and control disease. Although we describe some possible mechanisms of Helicobacter and Salmonella persistence, we actually know very little about how these pathogens survive for long periods of time in the mammalian host in the presence of immunosurveillance. In addition, our current understanding of disease transmission comes largely from retrospective epidemiological analysis and mathematical modeling of infectious disease transmission within natural populations. Future applications of genome-based techniques, including high throughput sequencing analysis of libraries of bacterial mutants, bacterial and host gene expression profiling, and system-wide microbiome analyses, as well as metabolomics, will allow further investigation of the fundamental genetics and immune responses of bacterial persistence and transmission. We believe that an increased understanding of the molecular mechanisms that control host-pathogen interactions could provide new targets to disable persistence and transmission of pathogens with preventative and/or therapeutic interventions.

\section{ACKNOWLEDGMENTS}

I thank Sara Fisher for critical reading of this review. I am very grateful to Dr. Manuel Amieva for providing insight, helpful suggestions, and figures.

\section{REFERENCES}

* Reference is also in this collection.

Alegado RA, Tan MW. 2008. Resistance to antimicrobial peptides contributes to persistence of Salmonella typhi- 
murium in the C. elegans intestine. Cell Microbiol 10: $1259-1273$.

Amieva MR, El-Omar EM. 2008. Host-bacterial interactions in Helicobacter pylori infection. Gastroenterology 134: 306-323.

Amieva MR, Vogelmann R, Covacci A, Tompkins LS, Nelson WJ, Falkow S. 2003. Disruption of the epithelial apicaljunctional complex by Helicobacter pylori CagA. Science 300: 1430-1434.

Andersen-Nissen E, Smith KD, Strobe KL, Barrett SL, Cookson BT, Logan SM, Aderem A. 2005. Evasion of Toll-like receptor 5 by flagellated bacteria. Proc Natl Acad Sci 102: 9247-9252.

Asahi M, Azuma T, Ito S, Ito Y, Suto H, Nagai Y, Tsubokawa M, Tohyama Y, Maeda S, Omata M, et al. 2000. Helicobacter pylori CagA protein can be tyrosine phosphorylated in gastric epithelial cells. J Exp Med 191: 593-602.

Backert S, Clyne M. 2011. Pathogenesis of Helicobacter pylori infection. Helicobacter 16: 19-25.

Backert S, Ziska E, Brinkmann V, Zimny-Arndt U, Fauconnier A, Jungblut PR, Naumann M, Meyer TF. 2000. Translocation of the Helicobacter pylori CagA protein in gastric epithelial cells by a type IV secretion apparatus. Cell Microbiol 2: 155-164.

Backert S, Tegtmeyer N, Selbach M. 2010. The versatility of Helicobacter pylori CagA effector protein functions: The master key hypothesis. Helicobacter 15: 163-176.

Backert S, Clyne M, Tegtmeyer N. 2011. Molecular mechanisms of gastric epithelial cell adhesion and injection of CagA by Helicobacter pylori. Cell Commun Signal 9: 28.

Bader MW, Sanowar S, Daley ME, Schneider AR, Cho U, Xu W, Klevit RE, Le Moual H, Miller SI. 2005. Recognition of antimicrobial peptides by a bacterial sensor kinase. Cell 122: $461-472$.

Bagnoli F, Buti L, Tompkins L, Covacci A, Amieva MR. 2005. Helicobacter pylori $\mathrm{CagA}$ induces a transition from polarized to invasive phenotypes in MDCK cells. Proc Natl Acad Sci 102: 16339-16344.

Baker S, Dougan G. 2007. The genome of Salmonella enterica serovar Typhi. Clin Infect Dis 45: S29-S33.

Bardhan PK. 1997. Epidemiological features of Helicobacter pylori infection in developing countries. Clin Infect Dis 25: 973-978.

Barman M, Unold D, Shifley K, Amir E, Hung K, Bos N, Salzman N. 2008. Enteric salmonellosis disrupts the microbial ecology of the murine gastrointestinal tract. Infect Immun 76: 907-915.

Bauer-Garland J, Frye JG, Gray JT, Berrang ME, Harrison MA, Fedorka-Cray PJ. 2006. Transmission of Salmonella enterica serotype Typhimurium in poultry with and without antimicrobial selective pressure. J Appl Microbiol 101: $1301-1308$.

* Bäumler A, Fang FC. 2013. Host specificity of bacterial pathogens. Cold Spring Harb Perspect Med doi: 10.1101/ cshperspect.a010041.

Bearson BL, Wilson L, Foster JW. 1998. A low pH-inducible, PhoPQ-dependent acid tolerance response protects Salmonella typhimurium against inorganic acid stress. J Bacteriol 180: 2409-2417.
Helicobacter/Salmonella: Infection Strategies

Bolam DN, Sonnenburg JL. 2011. Mechanistic insight into polysaccharide use within the intestinal microbiota. Gut Microbes 2: 86-90.

Brodsky IE, Ghori N, Falkow S, Monack D. 2005. Mig-14 is an inner membrane-associated protein that promotes Salmonella typhimurium resistance to CRAMP, survival within activated macrophages and persistent infection. Mol Microbiol 55: 954-972.

Brown LM. 2000. Helicobacter pylori: Epidemiology and routes of transmission. Epidemiol Rev 22: 283-297.

Cash HL, Whitham CV, Behrendt CL, Hooper LV. 2006. Symbiotic bacteria direct expression of an intestinal bactericidal lectin. Science 313: 1126-1130.

Cheminay C, Mohlenbrink A, Hensel M. 2005. Intracellular Salmonella inhibit antigen presentation by dendritic cells. J Immunol 174: 2892-2899.

Cirillo DM, Valdivia RH, Monack DM, Falkow S. 1998. Macrophage-dependent induction of the Salmonella pathogenicity island 2 type III secretion system and its role in intracellular survival. Mol Microbiol 30: 175-188.

Crawford RW, Gibson DL, Kay WW, Gunn JS. 2008. Identification of a bile-induced exopolysaccharide required for Salmonella biofilm formation on gallstone surfaces. Infect Immun 76: 5341-5349.

Crawford RW, Rosales-Reyes R, Ramirez-Aguilar Mde L, Chapa-Azuela O, Alpuche-Aranda C, Gunn JS. 2010. Gallstones play a significant role in Salmonella spp. gallbladder colonization and carriage. Proc Natl Acad Sci 107: 4353-4358.

Croxen MA, Sisson G, Melano R, Hoffman PS. 2006. The Helicobacter pylori chemotaxis receptor TlpB (HP0103) is required for $\mathrm{pH}$ taxis and for colonization of the gastric mucosa. J Bacteriol 188: 2656-2665.

Deiwick J, Nikolaus T, Shea JE, Gleeson C, Holden DW, Hensel M. 1998. Mutations in Salmonella pathogenicity island 2 (SPI2) genes affecting transcription of SPI1 genes and resistance to antimicrobial agents. J Bacteriol 180: 4775-4780.

Detweiler CS, Monack DM, Brodsky IE, Mathew H, Falkow S. 2003. virK, somA and $\mathrm{rcsC}$ are important for systemic Salmonella enterica serovar Typhimurium infection and cationic peptide resistance. Mol Microbiol 48: 385-400.

Dhanoa A, Fatt QK. 2009. Non-typhoidal Salmonella bacteraemia: Epidemiology, clinical characteristics and its association with severe immunosuppression. Ann Clin Microbiol Antimicrob 8: 15.

Dinbar A, Altmann G, Tulcinsky DB. 1969. The treatment of chronic biliary salmonella carriers. Am J Med 47: 236242.

Dorsey CW, Laarakker MC, Humphries AD, Weening EH, Bäumler AJ. 2005. Salmonella enterica serotype Typhimurium MisL is an intestinal colonization factor that binds fibronectin. Mol Microbiol 57: 196-211.

Dougan G, John V, Palmer S, Mastroeni P. 2011. Immunity to salmonellosis. Immunol Rev 240: 196-210.

Ebert D, Bull JJ. 2003. Challenging the trade-off model for the evolution of virulence: Is virulence management feasible? Trends Microbiol 11: 15-20.

Endt K, Stecher B, Chaffron S, Slack E, Tchitchek N, Benecke A, Van Maele L, Sirard JC, Mueller AJ, Heikenwalder M, et al. 2010. The microbiota mediates pathogen clearance 
D.M. Monack

from the gut lumen after non-typhoidal Salmonella diarrhea. PLoS Pathog 6: e1001097.

Erickson KD, Detweiler CS. 2006. The Rcs phosphorelay system is specific to enteric pathogens/commensals and activates ydeI, a gene important for persistent Salmonella infection of mice. Mol Microbiol 62: 883-894.

Falush D, Wirth T, Linz B, Pritchard JK, Stephens M, Kidd M, Blaser MJ, Graham DY, Vacher S, Perez-Perez GI, et al. 2003. Traces of human migrations in Helicobacter pylori populations. Science 299: 1582-1585.

Foster JW. 1995. Low $\mathrm{pH}$ adaptation and the acid tolerance response of Salmonella typhimurium. Crit Rev Microbiol 21: 215-237.

Galan JE. 2001. Salmonella interactions with host cells: Type III secretion at work. Annu Rev Cell Dev Biol 17: 53-86.

Gal-Mor O, Gibson DL, Baluta D, Vallance BA, Finlay BB, 2008. A novel secretion pathway of Salmonella enterica acts as an antivirulence modulator during salmonellosis. PLoS Pathog 4: e1000036.

Gewirtz AT, Yu Y, Krishna US, Israel DA, Lyons SL, Peek RM Jr. 2004. Helicobacter pylori flagellin evades toll-like receptor 5-mediated innate immunity. J Infect Dis 189: 1914-1920.

Glynn MK, Reddy V, Hutwagner L, Rabatsky-Ehr T, Shiferaw B, Vugia DJ, Segler S, Bender J, Barrett TJ, Angulo FJ. 2004. Prior antimicrobial agent use increases the risk of sporadic infections with multidrug-resistant Salmonella enterica serotype Typhimurium: A FoodNet case-control study, 1996-1997. Clin Infect Dis 38: S227-S236.

Gonzalez-Escobedo G, Marshall JM, Gunn JS. 2011. Chronic and acute infection of the gall bladder by Salmonella Typhi: Understanding the carrier state. Nat Rev Microbiol 9: 9-14.

Gordon MA, Graham SM, Walsh AL, Wilson L, Phiri A, Molyneux E, Zijlstra EE, Heyderman RS, Hart CA, Molyneux ME. 2008. Epidemics of invasive Salmonella enterica serovar enteritidis and S. enterica serovar Typhimurium infection associated with multidrug resistance among adults and children in Malawi. Clin Infect Dis $\mathbf{4 6}$ 963-969.

Govoni G, Vidal S, Cellier M, Lepage P, Malo D, Gros P. 1995. Genomic structure, promoter sequence, and induction of expression of the mouse Nramp1 gene in macrophages. Genomics 27: 9-19.

Groisman EA, Kayser J, Soncini FC. 1997. Regulation of polymyxin resistance and adaptation to low- $\mathrm{Mg} 2^{+}$environments. J Bacteriol 179: 7040-7045.

Guina T, Yi EC, Wang H, Hackett M, Miller SI. 2000. A PhoP-regulated outer membrane protease of Salmonella enterica serovar Typhimurium promotes resistance to $\alpha$ helical antimicrobial peptides. J Bacteriol 182: $4077-$ 4086.

Halici S, Zenk SF, Jantsch J, Hensel M. 2008. Functional analysis of the Salmonella pathogenicity island 2-mediated inhibition of antigen presentation in dendritic cells. Infect Immun 76: 4924-4933.

Hall-Stoodley L, Stoodley P. 2009. Evolving concepts in biofilm infections. Cell Microbiol 11: 1034-1043.

Handa O, Naito Y, Yoshikawa T. 2007. CagA protein of Helicobacter pylori: A hijacker of gastric epithelial cell signaling. Biochem Pharmacol 73: 1697-1702.
Haraga A, Ohlson MB, Miller SI. 2008. Salmonellae interplay with host cells. Nat Rev Microbiol 6: 53-66.

Hatakeyama M. 2004. Oncogenic mechanisms of the Helicobacter pylori CagA protein. Nat Rev Cancer 4: 688-694.

Hatakeyama M. 2008. Linking epithelial polarity and carcinogenesis by multitasking Helicobacter pylori virulence factor CagA. Oncogene 27: 7047-7054.

Helaine S, Thompson JA, Watson KG, Liu M, Boyle C, Holden DW. 2010. Dynamics of intracellular bacterial replication at the single cell level. Proc Natl Acad Sci 107: 37463751.

Hensel M, Shea JE, Waterman SR, Mundy R, Nikolaus T, Banks G, Vazquez-Torres A, Gleeson C, Fang FC, Holden DW. 1998. Genes encoding putative effector proteins of the type III secretion system of Salmonella pathogenicity island 2 are required for bacterial virulence and proliferation in macrophages. Mol Microbiol 30: 163-174.

Hesse M, Piccirillo CA, Belkaid Y, Prufer J, Mentink-Kane M, Leusink M, Cheever AW, Shevach EM, Wynn TA. 2004. The pathogenesis of schistosomiasis is controlled by cooperating IL-10-producing innate effector and regulatory T cells. J Immunol 172: 3157-3166.

Hessey SJ, Spencer J, Wyatt JI, Sobala G, Rathbone BJ, Axon AT, Dixon MF. 1990. Bacterial adhesion and disease activity in Helicobacter associated chronic gastritis. Gut 31: 134-138.

Hisaeda H, Maekawa Y, Iwakawa D, Okada H, Himeno K, Kishihara K, Tsukumo S, Yasutomo K. 2004. Escape of malaria parasites from host immunity requires $\mathrm{CD} 4^{+}$ $\mathrm{CD} 25^{+}$regulatory T cells. Nat Med 10: $29-30$.

Hormaeche CE. 1979. Natural resistance to Salmonella typhimurium in different inbred mouse strains. Immunology 37: 311-318.

Howitt MR, Lee JY, Lertsethtakarn P, Vogelmann R, Joubert LM, Ottemann KM, Amieva MR. 2011. ChePep controls Helicobacter pylori infection of the gastric glands and chemotaxis in the Epsilonproteobacteria. MBio 2: e00098-11.

Humphries AD, Townsend SM, Kingsley RA, Nicholson TL, Tsolis RM, Bäumler AJ. 2001. Role of fimbriae as antigens and intestinal colonization factors of Salmonella serovars. FEMS Microbiol Lett 201: 121-125.

Hunt RH. 1996. The role of Helicobacter pylori in pathogenesis: The spectrum of clinical outcomes. Scand J Gastroenterol Suppl 220: 3-9.

Ibarra JA, Steele-Mortimer O. 2009. Salmonella-The ultimate insider. Salmonella virulence factors that modulate intracellular survival. Cell Microbiol 11: 1579-1586.

Ilver D, Arnqvist A, Ogren J, Frick IM, Kersulyte D, Incecik ET, Berg DE, Covacci A, Engstrand L, Boren T. 1998. Helicobacter pylori adhesin binding fucosylated histoblood group antigens revealed by retagging. Science 279: 373-377.

Johanns TM, Ertelt JM, Rowe JH, Way SS. 2010. Regulatory $\mathrm{T}$ cell suppressive potency dictates the balance between bacterial proliferation and clearance during persistent Salmonella infection. PLoS Pathog 6: e1001043.

Jones BD, Falkow S. 1996. Salmonellosis: Host immune responses and bacterial virulence determinants. Annu Rev Immunol 14: 533-561. 
Jones BD, Ghori N, Falkow S. 1994. Salmonella typhimurium initiates murine infection by penetrating and destroying the specialized epithelial M cells of the Peyer's patches. $J$ Exp Med 180: 15-23.

Kariuki S, Revathi G, Kariuki N, Kiiru J, Mwituria J, Muyodi J, Githinji JW, Kagendo D, Munyalo A, Hart CA. 2006. Invasive multidrug-resistant non-typhoidal Salmonella infections in Africa: Zoonotic or anthroponotic transmission? J Med Microbiol 55: 585-591.

Kingsley RA, van Amsterdam K, Kramer N, Bäumler AJ. 2000. The shdA gene is restricted to serotypes of Salmonella enterica subspecies I and contributes to efficient and prolonged fecal shedding. Infect Immun 68: 2720-2727.

Kingsley RA, Santos RL, Keestra AM, Adams LG, Bäumler AJ. 2002a. Salmonella enterica serotype Typhimurium ShdA is an outer membrane fibronectin-binding protein that is expressed in the intestine. Mol Microbiol 43: 895905.

Kingsley RA, Weening EH, Keestra AM, Bäumler AJ. 2002b. Population heterogeneity of Salmonella enterica serotype Typhimurium resulting from phase variation of the lpf operon in vitro and in vivo. J Bacteriol 184: 2352-2359.

Kingsley RA, Abi Ghanem D, Puebla-Osorio N, Keestra AM, Berghman L, Bäumler AJ. 2004. Fibronectin binding to the Salmonella enterica serotype Typhimurium ShdA autotransporter protein is inhibited by a monoclonal antibody recognizing the A3 repeat. J Bacteriol 186: 49314939.

Kivi M, Johansson AL, Reilly M, Tindberg Y. 2005. Helicobacter pylori status in family members as risk factors for infection in children. Epidemiol Infect 133: 645-652.

Knodler LA, Vallance BA, Celli J, Winfree S, Hansen B, Montero M, Steele-Mortimer O. 2010. Dissemination of invasive Salmonella via bacterial-induced extrusion of mucosal epithelia. Proc Natl Acad Sci 107: $17733-$ 17738.

Kohbata S, Yokoyama H, Yabuuchi E. 1986. Cytopathogenic effect of Salmonella typhi GIFU 10007 on M cells of murine ileal Peyer's patches in ligated ileal loops: An ultrastructural study. Microbiol Immunol 30: 1225-1237.

Lawley TD, Chan K, Thompson LJ, Kim CC, Govoni GR, Monack DM. 2006. Genome-wide screen for Salmonella genes required for long-term systemic infection of the mouse. PLoS Pathog 2: e11.

Lawley TD, Bouley DM, Hoy YE, Gerke C, Relman DA, Monack DM. 2008. Host transmission of Salmonella enterica serovar Typhimurium is controlled by virulence factors and indigenous intestinal microbiota. Infect Immun 76: 403-416.

Lee IS, Lin J, Hall HK, Bearson B, Foster JW. 1995. The stationary-phase sigma factor sigma $\mathrm{S}$ (RpoS) is required for a sustained acid tolerance response in virulent Salmonella typhimurium. Mol Microbiol 17: 155-167.

Lertsethtakarn P, Ottemann KM, Hendrixson DR. 2011. Motility and chemotaxis in Campylobacter and Helicobacter. Annu Rev Microbiol 65: 389-410.

Levine MM, Black RE, Lanata C. 1982. Precise estimation of the numbers of chronic carriers of Salmonella typhi in Santiago, Chile, an endemic area. J Infect Dis 146: 724726.

Lin J, Lee IS, Frey J, Slonczewski JL, Foster JW. 1995. Comparative analysis of extreme acid survival in Salmonella typhimurium, Shigella flexneri, and Escherichia coli. J Bacteriol 177: 4097-4104.

Linz B, Balloux F, Moodley Y, Manica A, Liu H, Roumagnac P, Falush D, Stamer C, Prugnolle F, van der Merwe SW, et al. 2007. An African origin for the intimate association between humans and Helicobacter pylori. Nature 445: 915-918.

Lipsitch M, Moxon ER. 1997. Virulence and transmissibility of pathogens: What is the relationship? Trends Microbio 5: 31-37.

Long TT, Nakazawa S, Onizuka S, Huaman MC, Kanbara H. 2003. Influence of $\mathrm{CD} 4^{+} \mathrm{CD} 25^{+} \mathrm{T}$ cells on Plasmodium berghei NK65 infection in BALB/c mice. Int J Parasitol 33: $175-183$.

Mahdavi J, Sonden B, Hurtig M, Olfat FO, Forsberg L, Roche N, Angstrom J, Larsson T, Teneberg S, Karlsson KA, et al. 2002. Helicobacter pylori SabA adhesin in persistent infection and chronic inflammation. Science 297: 573-578.

Mastroeni P, Grant AJ. 2011. Spread of Salmonella enterica in the body during systemic infection: Unravelling host and pathogen determinants. Expert Rev Mol Med 13: e12.

Mastroeni P, Menager N. 2003. Development of acquired immunity to Salmonella. J Med Microbiol 52: 453-459.

Mazmanian SK, Liu CH, Tzianabos AO, Kasper DL. 2005. An immunomodulatory molecule of symbiotic bacteria directs maturation of the host immune system. Cell 122: $107-118$.

McCallion WA, Murray LJ, Bailie AG, Dalzell AM, O'Reilly DP, Bamford KB. 1996. Helicobacter pylori infection in children: Relation with current household living conditions. Gut 39: 18-21.

McGhie EJ, Brawn LC, Hume PJ, Humphreys D, Koronakis V. 2009. Salmonella takes control: Effector-driven manipulation of the host. Curr Opin Microbiol 12: 117-124.

McLaughlin LM, Govoni GR, Gerke C, Gopinath S, Peng K, Laidlaw G, Chien YH, Jeong HW, Li Z, Brown MD, et al. 2009. The Salmonella SPI2 effector SseI mediates longterm systemic infection by modulating host cell migration. PLoS Pathog 5: e1000671.

Mecsas J, Bilis I, Falkow S. 2001. Identification of attenuated Yersinia pseudotuberculosis strains and characterization of an orogastric infection in BALB/c mice on day 5 postinfection by signature-tagged mutagenesis. Infect Immun 69: $2779-2787$.

Mendez S, Reckling SK, Piccirillo CA, Sacks D, Belkaid Y. 2004. Role for $\mathrm{CD} 4{ }^{+} \mathrm{CD} 25^{+}$regulatory T cells in reactivation of persistent leishmaniasis and control of concomitant immunity. J Exp Med 200: 201-210.

Merrell DS, Butler SM, Qadri F, Dolganov NA, Alam A, Cohen MB, Calderwood SB, Schoolnik GK, Camilli A. 2002. Host-induced epidemic spread of the cholera bacterium. Nature 417: 642-645.

Merrell DS, Goodrich ML, Otto G, Tompkins LS, Falkow S. 2003. pH-regulated gene expression of the gastric pathogen Helicobacter pylori. Infect Immun 71: 3529-3539.

Meynell GG. 1957. The applicability of the hypothesis of independent action to fatal infections in mice given Salmonella typhimurium by mouth. J Gen Microbiol 16: 396-404.

Meynell GG, Stocker BA. 1957. Some hypotheses on the aetiology of fatal infections in partially resistant hosts 
D.M. Monack

and their application to mice challenged with Salmonella paratyphi-B or Salmonella typhimurium by intraperitoneal injection. J Gen Microbiol 16: 38-58.

Miao EA, Miller SI. 2000. A conserved amino acid sequence directing intracellular type III secretion by Salmonella typhimurium. Proc Natl Acad Sci 97: 7539-7544.

Mittrucker HW, Raupach B, Kohler A, Kaufmann SH. 2000. Cutting edge: Role of B lymphocytes in protective immunity against Salmonella typhimurium infection. J Immunol 164: 1648-1652.

Monack DM, Bouley DM, Falkow S. 2004a. Salmonella typhimurium persists within macrophages in the mesenteric lymph nodes of chronically infected $\mathrm{Nramp}^{+/+}$mice and can be reactivated by IFN- $\gamma$ neutralization. J Exp Med 199: $231-241$

Monack DM, Mueller A, Falkow S. 2004b. Persistent bacterial infections: The interface of the pathogen and the host immune system. Nat Rev Microbiol 2: 747-765.

Moran AP. 2007. Lipopolysaccharide in bacterial chronic infection: Insights from Helicobacter pylori lipopolysaccharide and lipid A. Int J Med Microbiol 297: 307-319.

Moran AP. 2008. Relevance of fucosylation and Lewis antigen expression in the bacterial gastroduodenal pathogen Helicobacter pylori. Carbohydr Res 343: 1952-1965.

Murata-Kamiya N. 2011. Pathophysiological functions of the CagA oncoprotein during infection by Helicobacter pylori. Microbes Infect 13: 799-807.

Murata-Kamiya N, Kurashima Y, Teishikata Y, Yamahashi Y, Saito Y, Higashi H, Aburatani H, Akiyama T, Peek RM Jr, Azuma T, et al. 2007. Helicobacter pylori CagA interacts with $\mathrm{E}$-cadherin and deregulates the $\beta$-catenin signal that promotes intestinal transdifferentiation in gastric epithelial cells. Oncogene 26: 4617-4626.

Nix RN, Altschuler SE, Henson PM, Detweiler CS. 2007. Hemophagocytic macrophages harbor Salmonella enterica during persistent infection. PLoS Pathog 3: e193.

Odenbreit S, Puls J, Sedlmaier B, Gerland E, Fischer W, Haas R. 2000. Translocation of Helicobacter pylori CagA into gastric epithelial cells by type IV secretion. Science 287: 1497-1500.

Ottemann KM, Lowenthal AC. 2002. Helicobacter pylori uses motility for initial colonization and to attain robust infection. Infect Immun 70: 1984-1990.

Parry CM, Hien TT, Dougan G, White NJ, Farrar JJ. 2002. Typhoid fever. N Engl J Med 347: 1770-1782.

Peek RM Jr. 2005. Orchestration of aberrant epithelial signaling by Helicobacter pylori CagA. Sci STKE 2005: pe14.

Pflock M, Kennard S, Finsterer N, Beier D. 2006. Acid-responsive gene regulation in the human pathogen Helicobacter pylori. J Biotechnol 126: 52-60.

Qiao XT, Ziel JW, McKimpson W, Madison BB, Todisco A, Merchant JL, Samuelson LC, Gumucio DL. 2007. Prospective identification of a multilineage progenitor in murine stomach epithelium. Gastroenterology 133: 1989-1998.

Rakoff-Nahoum S, Paglino J, Eslami-Varzaneh F, Edberg S, Medzhitov R. 2004. Recognition of commensal microflora by toll-like receptors is required for intestinal homeostasis. Cell 118: 229-241.

Retamal P, Castillo-Ruiz M, Villagra NA, Morgado J, Mora GC. 2010. Modified intracellular-associated phenotypes in a recombinant Salmonella Typhi expressing $S$. Typhimurium SPI-3 sequences. PloS ONE 5: e9394.

Riley LW, Cohen ML, Seals JE, Blaser MJ, Birkness KA, Hargrett NT, Martin SM, Feldman RA. 1984. Importance of host factors in human salmonellosis caused by multiresistant strains of Salmonella. J Infect Dis 149: 878-883.

Saadat I, Higashi H, Obuse C, Umeda M, Murata-Kamiya N, Saito Y, Lu H, Ohnishi N, Azuma T, Suzuki A, et al. 2007. Helicobacter pylori CagA targets PAR1/MARK kinase to disrupt epithelial cell polarity. Nature 447: 330-333.

Sabbagh SC, Forest CG, Lepage C, Leclerc JM, Daigle F. 2010. So similar, yet so different: Uncovering distinctive features in the genomes of Salmonella enterica serovars Typhimurium and Typhi. FEMS Microbiol Lett 305: $1-13$.

Salzman NH. 2011. Microbiota-immune system interaction: An uneasy alliance. Curr Opin Microbiol 14: 99105.

Scher K, Romling U, Yaron S. 2005. Effect of heat, acidification, and chlorination on Salmonella enterica serovar typhimurium cells in a biofilm formed at the air-liquid interface. Appl Environ Microbiol 71: 1163-1168.

Schreiber S, Konradt M, Groll C, Scheid P, Hanauer G, Werling HO, Josenhans C, Suerbaum S. 2004. The spatial orientation of Helicobacter pylori in the gastric mucus. Proc Natl Acad Sci 101: 5024-5029.

Schreiber S, Bucker R, Groll C, Azevedo-Vethacke M, Garten D, Scheid P, Friedrich S, Gatermann S, Josenhans C, Suerbaum S. 2005. Rapid loss of motility of Helicobacter pylori in the gastric lumen in vivo. Infect Immun 73: 1584-1589.

Segal ED, Cha J, Lo J, Falkow S, Tompkins LS. 1999. Altered states: Involvement of phosphorylated CagA in the in duction of host cellular growth changes by Helicobacter pylori. Proc Natl Acad Sci 96: 14559-14564.

Sekirov I, Russell SL, Antunes LC, Finlay BB. 2010. Gut microbiota in health and disease. Physiol Rev 90: 859_ 904.

Sigauque B, Roca A, Mandomando I, Morais L, Quinto L, Sacarlal J, Macete E, Nhamposa T, Machevo S, Aide P, et al. 2009. Community-acquired bacteremia among children admitted to a rural hospital in Mozambique. Pediatr Infect Dis J 28: 108-113.

Song J, Gao X, Galan JE. 2013. Structure and function of the Salmonella Typhi chimaeric $\mathrm{A}_{2} \mathrm{~B}_{5}$ typhoid toxin. Nature 499: $350-354$

Sonnenburg JL, Chen CT, Gordon JI. 2006. Genomic and metabolic studies of the impact of probiotics on a model gut symbiont and host. PLoS Biol 4: e413.

Sonnenburg ED, Zheng H, Joglekar P, Higginbottom SK, Firbank SJ, Bolam DN, Sonnenburg JL. 2010. Specificity of polysaccharide use in intestinal bacteroides species determines diet-induced microbiota alterations. Cell 141: $1241-1252$.

Spano S, Galan JE. 2012. A Rab32-dependent pathway contributes to Salmonella Typhi host restriction. Science 338 960-963.

Spector MP. 1998. The starvation-stress response (SSR) of Salmonella. Adv Microb Physiol 40: 233-279. 
Stecher B, Hardt WD. 2011. Mechanisms controlling pathogen colonization of the gut. Curr Opin Microbiol 14: 82-91.

Stecher B, Robbiani R, Walker AW, Westendorf AM, Barthel M, Kremer M, Chaffron S, Macpherson AJ, Buer J, Parkhill J, et al. 2007. Salmonella enterica serovar Typhimurium exploits inflammation to compete with the intestinal microbiota. PLoS Biol 5: 2177-2189.

Steer HW. 1984. Surface morphology of the gastroduodenal mucosa in duodenal ulceration. Gut 25: 1203-1210.

Stein M, Rappuoli R, Covacci A. 2000. Tyrosine phosphorylation of the Helicobacter pylori CagA antigen after cagdriven host cell translocation. Proc Natl Acad Sci 97: $1263-1268$.

Suvas S, Kumaraguru U, Pack CD, Lee S, Rouse BT. 2003. $\mathrm{CD} 4{ }^{+} \mathrm{CD} 25^{+} \mathrm{T}$ cells regulate virus-specific primary and memory CD8 ${ }^{+} \mathrm{T}$ cell responses. J Exp Med 198: 889-901.

Suvas S, Azkur AK, Kim BS, Kumaraguru U, Rouse BT. 2004 $\mathrm{CD} 4{ }^{+} \mathrm{CD} 25^{+}$regulatory $\mathrm{T}$ cells control the severity of viral immunoinflammatory lesions. J Immunol 172: 4123-4132.

Suzuki T, Matsuo K, Sawaki A, Ito H, Hirose K, Wakai K, Sato S, Nakamura T, Yamao K, Ueda R, et al. 2006. Systematic review and meta-analysis: Importance of CagA status for successful eradication of Helicobacter pylori infection. Aliment Pharmacol Ther 24: 273-280.

Tan S, Tompkins LS, Amieva MR. 2009. Helicobacter pylori usurps cell polarity to turn the cell surface into a replicative niche. PLoS Pathog 5: e1000407.

Tan S, Noto JM, Romero-Gallo J, Peek RM Jr, Amieva MR. 2011. Helicobacter pylori perturbs iron trafficking in the epithelium to grow on the cell surface. PLoS Pathog 7: e1002050.

Tegtmeyer N, Wessler S, Backert S. 2011. Role of the cagpathogenicity island encoded type IV secretion system in Helicobacter pylori pathogenesis. FEBS J 278: 1190-1202.

Terry K, Williams SM, Connolly L, Ottemann KM. 2005. Chemotaxis plays multiple roles during Helicobacter pylori animal infection. Infect Immun 73: 803-811.

Thompson LJ, Dunstan SJ, Dolecek C, Perkins T, House D, Dougan G, Nguyen TH, Tran TP, Doan CD, Le TP, et al. 2009. Transcriptional response in the peripheral blood of patients infected with Salmonella enterica serovar Typhi. Proc Natl Acad Sci 106: 22433-22438.

Tobar JA, Carreno LJ, Bueno SM, Gonzalez PA, Mora JE, Quezada SA, Kalergis AM. 2006. Virulent Salmonella enterica serovar Typhimurium evades adaptive immunity by preventing dendritic cells from activating $\mathrm{T}$ cells. Infect Immun 74: 6438-6448.

Tran QT, Gomez G, Khare S, Lawhon SD, Raffatellu M, Bäumler AJ, Ajithdoss D, Dhavala S, Adams LG. 2010. The Salmonella enterica serotype Typhi Vi capsular antigen is expressed after the bacterium enters the ileal mucosa. Infect Immun 78: 527-535.

Trombert AN, Rodas PI, Mora GC. 2011. Reduced invasion to human epithelial cell lines of Salmonella enterica serovar Typhi carrying $S$. Typhimurium sopD2. FEMS Microbiol Lett 322: 150-156.

Tsolis RM, Young GM, Solnick JV, Bäumler AJ. 2008. From bench to bedside: Stealth of enteroinvasive pathogens. Nat Rev Microbiol 6: 883-892.
Uemura N, Okamoto S, Yamamoto S, Matsumura N, Yamaguchi S, Yamakido M, Taniyama K, Sasaki N, Schlemper RJ. 2001. Helicobacter pylori infection and the development of gastric cancer. N Engl J Med 345: 784-789.

Uzonna JE, Wei G, Yurkowski D, Bretscher P. 2001. Immune elimination of Leishmania major in mice: Implications for immune memory, vaccination, and reactivation disease. J Immunol 167: 6967-6974.

Valdez Y, Ferreira RB, Finlay BB. 2009. Molecular mechanisms of Salmonella virulence and host resistance. Curr Top Microbiol Immunol 337: 93-127.

Vazquez-Torres A, Jones-Carson J, Bäumler AJ, Falkow S, Valdivia R, Brown W, Le M, Berggren R, Parks WT, Fang FC. 1999. Extraintestinal dissemination of Salmonella by CD18-expressing phagocytes. Nature 401: 804808.

Vidal SM, Malo D, Vogan K, Skamene E, Gros P. 1993. Natural resistance to infection with intracellular parasites: Isolation of a candidate for Bcg. Cell 73: 469-485.

Vogelsang TM, Boe J. 1948. Temporary and chronic carriers of Salmonella Typhi and Salmonella Paratyphi B. J Hyg (Lond) 46: 252-261.

Wagner C, Hensel M. 2011. Adhesive mechanisms of Salmonella enterica. Adv Exp Med Biol 715: 17-34.

Weening EH, Barker JD, Laarakker MC, Humphries AD, Tsolis RM, Bäumler AJ. 2005. The Salmonella enterica serotype Typhimurium $l p f, b c f, s t b$, stc, std, and $s t h$ fimbrial operons are required for intestinal persistence in mice. Infect Immun 73: 3358-3366.

Weyermann M, Adler G, Brenner H, Rothenbacher D. 2006. The mother as source of Helicobacter pylori infection. Epidemiology 17: 332-334.

White AP, Gibson DL, Kim W, Kay WW, Surette MG. 2006. Thin aggregative fimbriae and cellulose enhance longterm survival and persistence of Salmonella. J Bacteriol 188: 3219-3227.

White AP, Gibson DL, Grassl GA, Kay WW, Finlay BB, Vallance BA, Surette MG. 2008. Aggregation via the red, dry, and rough morphotype is not a virulence adaptation in Salmonella enterica serovar Typhimurium. Infect Immun 76: $1048-1058$.

Wijburg OL, Uren TK, Simpfendorfer K, Johansen FE, Brandtzaeg P, Strugnell RA. 2006. Innate secretory antibodies protect against natural Salmonella Typhimurium infection. J Exp Med 203: 21-26.

Williams SM, Chen YT, Andermann TM, Carter JE, McGee DJ, Ottemann KM. 2007. Helicobacter pylori chemotaxis modulates inflammation and bacterium-gastric epithelium interactions in infected mice. Infect Immun 75: 3747-3757.

Wilson RP, Raffatellu M, Chessa D, Winter SE, Tukel C, Bäumler AJ. 2008. The Vi-capsule prevents Toll-like receptor 4 recognition of Salmonella. Cell Microbiol 10: 876-890.

Winter SE, Raffatellu M, Wilson RP, Rüssmann H, Bäumler AJ. 2008. The Salmonella enterica serotype Typhi regulator TviA reduces interleukin-8 production in intestinal epithelial cells by repressing flagellin secretion. Cell Microbiol 10: 247-261.

Winter SE, Winter MG, Thiennimitr P, Gerriets VA, Nuccio SP, Rüssmann H, Bäumler AJ. 2009. The TviA auxiliary 
D.M. Monack

protein renders the Salmonella enterica serotype Typhi RcsB regulon responsive to changes in osmolarity. Mol Microbiol 74: 175-193.

Winter SE, Thiennimitr P, Winter MG, Butler BP, Huseby DL, Crawford RW, Russell JM, Bevins CL, Adams LG, Tsolis RM, et al. 2010. Gut inflammation provides a respiratory electron acceptor for Salmonella. Nature 467: 426-429.

Yen YF, Wang FD, Chiou CS, Chen YY, Lin ML, Chen TL, Liu CY. 2009. Prognostic factors and clinical features of non- typhoid Salmonella bacteremia in adults. J Chin Med Assoc 72: 408-413.

Young D, Hussell T, Dougan G. 2002. Chronic bacterial infections: Living with unwanted guests. Nat Immunol 3: $1026-1032$.

Zeaiter Z, Huynh HQ, Kanyo R, Stein M. 2008. CagA of Helicobacter pylori alters the expression and cellular distribution of host proteins involved in cell signaling. FEMS Microbiol Lett 288: 227-234. 


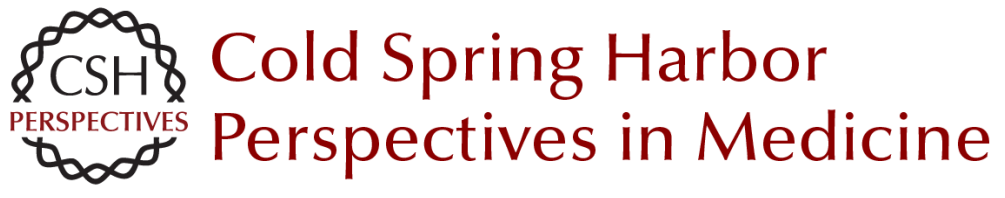

\section{Helicobacter and Salmonella Persistent Infection Strategies}

Denise M. Monack

Cold Spring Harb Perspect Med 2013; doi: 10.1101/cshperspect.a010348

Subject Collection Bacterial Pathogenesis

Therapeutic and Prophylactic Applications of Bacteriophage Components in Modern Medicine Sankar Adhya, Carl R. Merril and Biswajit Biswas

Vaccines, Reverse Vaccinology, and Bacterial Pathogenesis Isabel Delany, Rino Rappuoli and Kate L. Seib

Helicobacter and Salmonella Persistent Infection Strategies Denise M. Monack

Echoes of a Distant Past: The cag Pathogenicity Island of Helicobacter pylori Nicola Pacchiani, Stefano Censini, Ludovico Buti, et al.

RNA-Mediated Regulation in Pathogenic Bacteria Isabelle Caldelari, Yanjie Chao, Pascale Romby, et al.

The Pneumococcus: Epidemiology, Microbiology, and Pathogenesis

Birgitta Henriques-Normark and Elaine I. Tuomanen

Pathogenesis of Meningococcemia Mathieu Coureuil, Olivier Join-Lambert, Hervé Lécuyer, et al.

Chlamydial Intracellular Survival Strategies Robert J. Bastidas, Cherilyn A. Elwell, Joanne N. Engel, et al.
Mechanisms and Biological Roles of

Contact-Dependent Growth Inhibition Systems

Christopher S. Hayes, Sanna Koskiniemi, Zachary

C. Ruhe, et al.

A Genome-Wide Perspective of Human Diversity and Its Implications in Infectious Disease Jérémy Manry and Lluis Quintana-Murci

Host Specificity of Bacterial Pathogens Andreas Bäumler and Ferric C. Fang

The Inside Story of Shigella Invasion of Intestinal Epithelial Cells

Nathalie Carayol and Guy Tran Van Nhieu

Bartonella and Brucella--Weapons and Strategies for Stealth Attack

Houchaima Ben-Tekaya, Jean-Pierre Gorvel and Christoph Dehio

Concepts and Mechanisms: Crossing Host Barriers

Kelly S. Doran, Anirban Banerjee, Olivier Disson, et al.

Genome Dynamics in Legionella: The Basis of

Versatility and Adaptation to Intracellular

Replication

Laura Gomez-Valero and Carmen Buchrieser

Mechanisms of Francisella tularensis Intracellular

Pathogenesis

Jean Celli and Thomas C. Zahrt

For additional articles in this collection, see http://perspectivesinmedicine.cshlp.org/cgi/collection/ 